\title{
KONVERSI IDENTITAS PREMAN MENJADI LASKAR DI SOLO
}

\author{
Warsito \\ ayasyahid@gmail.com \\ Sekolah Tinggi Islam Al Mukmin Surakarta
}

DOI: $10.21580 /$ wa.v6i2.3167

\begin{abstract}
Thugs and soldiers are two different poles. Thugs carry out activities that are against religious norms while laskar carry out their activities including confrontation with thugs because they are motivated by religious norms. It becomes attractive when thugs turn into irregulars. Habitus preman who violently contradicts religious values is demanded to be in accordance with religious norms. How do they negotiate the old identity with the new identity? How is the influence of habitus on their religious practices and class activities? How to unite Islamic movements from various mass organizations and laskar? This habitus affects the behavior of the members of the laskar which are generally divided into two. Moderate laskar, laskar that adapts Islamic teachings in carrying out laskar activities, is not extreme in understanding, and accepts differences. Camouflage army, an army that uses thug logic to gain personal and group benefits but wears paramilitary attributes. One of the drivers of the unity between the elements of the ummah is the imagined common enemy. I have proven this with several recent incidents. Another laskar phenomenon is division due to the influence of globalization. The Syrian and Iraq wars influenced the views of the laskar who had the spirit of jihad. Divisions in Syria also contributed to the breakdown of the paramilitary groups. Some of them support ISIS while some others reject ISIS. ISIS's ideology of takfir is clouding divisions, they are kafir opponents of ISIS and governments other than the Islamic state led by alBaghdadi. This study uses qualitative data. Methods of data collection by observation, interviews and literature study in accordance with the theme.
\end{abstract}

Keywords: identity, Islamism, laskar 


\begin{abstract}
Abstrak
Preman dan laskar dua kutub yang berbeda. Preman melakukan aktivitas yang bertentangan dengan norma agama sementara laskar melakukan aktivitas mereka termasuk konfrontasi dengan preman karena terdorong norma agama. Menjadi menarik ketika preman berubah menjadi laskar. Habitus preman yang keras bertentangan dengan nilai agama dituntut selaras dengan norma-norma agama. Bagaimana mereka menegosiasikan identitas lama dengan identitas baru? Bagaimana pengaruh habitus dalam pengamalan keagamaan dan aktivitas kelaskaran mereka? Bagaimana menyatukan gerakan-gerakan Islam dari berbagai ormas dan laskar? Habitus ini mempengaruhi perilaku para anggota laskar yang secara umum dibagi menjadi dua. Laskar moderat, laskar yang menyesuaikan ajaran Islam dalam melakukan aktivitas laskar, tidak ekstrim dalam pemahaman, dan menerima perbedaan. Laskar kamuflase, laskar yang menggunakan logika preman dalam mendapat keuntungan pribadi maupun kelompok tetapi memakai atribut laskar. Salah satu pendorong kesatuan antara elemen umat adalah imajinasi musuh bersama (imagined common enemy) hal ini saya buktikan dengan beberapa kejadian yang terjadi baru-baru ini. Fenomena laskar yang lain adalah perpecahan karena pengaruh globalisasi. Perang Suriah dan Iraq mempengaruhi pandangan laskar yang memiliki semangat jihad. Perpecahan di Suriah ikut memecah persatuan laskar. Sebagian mereka mendukung ISIS sementara sebagian yang lain menolak ISIS. Ideologi takfir ISIS memperkeruh perpecahan, mereka mengkafirkan penentang ISIS dan pemerintah selain negara Islam pimpinan al-Baghdadi. Penelitian ini menggunakan data kualitatif. Metode pengumpulan data dengan observasi, interview dan studi pustaka yang sesuai dengan tema.
\end{abstract}

Kata Kunci: identitas, Islamism, laskar

\title{
A. Pendahuluan
}

Perubahan identitas dari preman menjadi preman bukan saja perubahan symbol dan bahasa melainkan juga perubahan budaya, pilihan partai, pilihan makanan dan minuman. Perubahan ini juga mempengaruhi struktur masyarakat dan pilihan pimpinan. Model gerakan perubahan sosial seperti ini sesuai dengan pendapat Durkheim. Dia berpendapat bahwa perubahan sosial berasal dari transformasi struktur budaya, ke struktur sosial dan terakhir ke struktur teknik. Perubahan pada sentimen-sentimen kolektif mengarah pembentukan sentimen mekanis. Perubahan ini akan mempengaruhi perubahan struktur sosial dan berakhir pada perubahan di lembaga-lembaga masyarakat atau struktur teknik. ${ }^{1}$

Laskar adalah realita kehidupan orang-orang muslim khususnya di Indonesia. Mereka entitas yang menarik untuk dikaji, tetapi secara umum studi tentang laskar membahas tentang tinjauan hukum terhadap tindakan-tindakan laskar yang arogan, radikal

${ }^{1}$ Kuntowijoyo, Paradigma Islam: Interpretasi Untuk Aksi (Bandung: Mizan, 1998), 340. 
dan ekstrem. Studi laskar mantan preman memiliki banyak dimensi yang unik, dari bagaimana mereka membangun identitas baru, bagaimana mendialoqkan identitas lama dengan identitas baru, dan bagaimana usaha mereka di ruang publik? Studi ini mencoba menjawab pertanyaan-pertanyaan itu dengan metode pengambilan data berupa wawancara, desk studi dengan mempelajari tulisan para sarjana tentang identitas, islamisme, dan gerakan sosial. Maka penulis berharap studi ini menambah teori tentang gerakan sosial Islam yang belum lama masuk dalam tataran ilmu sosial di Barat. Jika Asef Bayat mengajukan teori Imagined Solidarity untuk menggambarkan adanya bayangan yang mampu menyatukan gerakan islamisme, pada studi ini saya mengajukan teori imagined common enemy (imanjinasi musuh bersama). Hal ini saya usulkan karena laskar yang beragam sulit disatukan dengan tema ukhuwah tetapi mereka bisa bersatu menghadapi musuh yang sama.

\section{B. Pembahasan}

\section{Konversi Identitas Lama ke Identitas Baru}

Tanggal 21 Mei tahun 1998 merupakan hari bersejarah bagi gerakan Islamism di Indonesia. Pola pergerakan mereka berubah dari bawah tanah menuju pergerakan di permukaan. Perubahan ini diawali dengan mundurnya Presiden Republik Indonesia Soeharto setelah demo besar mahasiswa. Runtuhnya rezim otoriter membuka pintu kebebasan berpendapat, berekspresi, kebebasan press, kebebasan berkumpul, berdemontrasi, kebebasan bergabung dan membuat organisasi, kebebasan dari teror dan berbagai sloganslogan demokrasi. President Habibie merespon tuntutan reformasi dengan membuat berbagai kebijakan yang mendorong reformasi dan kebebasan. ${ }^{2}$ Keadaan ini dimanfaatkan oleh berbagai ideology yang tertekan oleh regim orde baru. Mereka muncul dengan berbagai nama ormas dan partai politik termasuk kelompok islamisme seperti Majelis Mujhidin, Hizbut Tahrir Indonesia, Jamaah Ikhwanul Muslimin Indonesia dan lain-lain. ${ }^{3}$

Perubahan iklim dari otoriter menjadi demokrasi memberi ruang gerak yang bebas bagi orang-orang untuk menyuarakan aspirasi mereka. Dengan dalil kebebasan berkumpul, membuat organisasi dan menyampaikan pendapat, kelompok Islamisme menyuarakan penegakan syari'at Islam di jalan-jalan, masjid-masjid dan tempat-tempat umum. Munculnya kelompok-kelompok Islam diikuti oleh kekuatan para militer mereka yang kemudian disebut laskar. Dengan dalil kebebasan, mereka menyusun kekuatan dan melakukan kegiatan konfrontatif terhadap kegiatan preman sekuler yang melanggar ajaran Islam. Kelompok informal yang baru ini terus membesar dan mampu menggusur kelompokkelompok preman sekuler di Solo. ${ }^{4}$

Pada dasarnya, proses kegiatan nahi mungkar ini mendapat perlawanan para preman sekuler sehingga terjadi beberapa kali bentrokan berskala kecil maupun yang luas. Sebagai

${ }^{2}$ Jacqueline AC Vel, Uma Politics: An Ethnography of Democratization in West Sumba, Indonesia, 19862006, vol. 260 (Brill, 2008), 114-18.

${ }^{3}$ Noorhaidi Hasan, Laskar Jihad: Islam, Militansi, Dan Pencarian Identitas Di Indonesia Pasca OrdeBaru (Jakarta: Pustaka LP3ES, 2008), 3.

${ }^{4}$ Noorhaidi Hasan, Laskar Jihad (Jakarta: Pustaka LP3ES, 2008), 2. 
contoh adalah pengerusakan warung doyong, bentrok di desa Losari 2008, bentrok di Kesumodilagan 2008 yang memakan korban Kipli selaku pimpinan geng preman Gondez, dan bentrok di desa Gandekan tahun 2012. Bentrokan-bentrokan ini berakhir dengan para preman yang mengaku kalah dan berjanji meninggalkan semua perilaku kemaksiatan di tempat umum. ${ }^{5}$ Dengan membesarnya kelompok laskar, terjadi konversi besar-besaran dari preman menjadi laskar. Konversi ini tidak terlepas dari kebijakan pemimpin laskar yang memberi tiga pilihan ketika akan terjadi konfrontasu antara dua kelompok tersebut. Pilihan itu adalah satu dilaporkan ke polisi dengan berbagai resiko hukum, kedua, bertaubat dengan konsekuensi mau melaksanakan sholat berjamaah yang kemudian bisa bergabung dengan laskar. Ketiga, konfrontasi fisik dengan laskar. Melihat pengalaman dari berbagai kejadian, mereka memilih pilihan kedua kemudian menggabungkan diri dengan laskar. ${ }^{6}$

Melihat kronologi pergerakan laskar dalam menangani preman sekuler dengan memberi pilihan taubat kemudian bisa bergabung dengan laskar membuat konversi besarbesaran preman menjadi anggota laskar. Menurut salah satu komandan tim Hisbah, dia menyatakan ada tiga motif preman bergabung dengan laskar, pertama karena mereka takut. Orang seperti ini mengubah penampilannya seperti penampilan laskar tetapi masih melakukan tindakan-tindakan preman. Sebuah kasus pelarian sepeda motor oleh oknum yang mengaku laskar yang kemudian diadili komandan. Kedua karena posisi dia di dunia preman sudah meredup dengan datangnya preman muda yang lebih kuat, kemudian dia bergabung dengan laskar untuk mengembalikan posisi sebagai orang yang disegani. Ketika karena mendapat wahyu. Tipe orang ketiga ini yang siap secara batin pada proses perubahan dan orang seperti ini bisa istiqomah.

Pembentukan identitas menurut Manuel Castells dipengaruhi oleh beberapa faktor, seperti; faktor sejarah, geografi, biologi, kumpulan memori, fantasi seseorang, kekuatan aparat dan wahyu agama. Sementara perubahan identitas secara kolektif, Castells membagi tiga macam pola pembentukan identitas. Pertama legitimizing identity, ini merupakan pembentukan identitas yang dilakukan oleh institusi atau pemerintahan. Kedua resistance identity, pembentukan identitas yang dibangun aktor yang kalah dan menjadi oposisi. Identitas ini bersifat perlawanan dan bertahan dalam prinsip-prinsip yang berbeda. Ketiga project identity, pembentukan identitas yang dilakukan para aktivis untuk mendefinisikan ulang posisi mereka di masyarakat. ${ }^{7}$

Dengan melihat model gerakan laskar, pendiri dan tujuannya, saya berpendapat bahwa proses perubahan identitas masuk dalam kategori resistance identity. Tujuan utama pembentukan laskar adalah menyiapkan paramiliter untuk mendukung tegaknya syari'at Islam di Indonesia dan membentuk mujahid yang membantu muslim lain di daerah konflik seperti Ambon, Poso, Kalimantan dan daerah-daerah lain. Hal ini sebagaimana pembentukan laskar Jihad, Laskar Pembela Islam, Front Pembela Islam Surakarta, Laskar Majelis Mujahidin, Laskar Santri, Laskar Hisbah dan lain-lain. Selain melakukan nahi

\footnotetext{
${ }^{5}$ Warsito, Preman Taubat (Solo: Penerbit al Aqwam, 2016), 111-18.

${ }^{6}$ Warsito, 112.

${ }^{7}$ Manuel Castells, The Power of Identity, Second (UK: Wiley-Blagkwell, 2009$), 7$.
} 
mungkar, mereka juga melakukan demo di jalan-jalan untuk menyerukan penerapan syari'at Islam di Indonesia. ${ }^{8}$

Musthafa berpendapat bahwa proses pembentukan identitas seorang muslim atau ikhwan melalui tiga tahapan utama. Pertama, Tahap penerangan (ta'rif) atau tahap propanda, memperkenalkan, menggambarkan ide (fikrah) dan menyampaikannya kepada khalayak ramai dan setiap lapisan masyarakat. Kedua, Tahap Pembinaan dan Pembentukan (takwin), yaitu tahapan pembentukan, memilih pendukung, menyiapkan pasukan, mujahid, dan mujahid dakwah serta mendidiknya. Ketiga, Tahap Pelaksanaan (Tanfidz), yaitu tahap beramal, berusaha, dan bergerak mencapai tujuan. ' Teori pembentukan identitas muslim yang digambarkan Musthafa dalam jamaah Ikhwanul Muslimin menjadi kritik terhadap pembentukan identitas laskar mantan preman di Tim Hisbah. Para pimpinan laskar ini melewatkan proses taqwin sebagai proses terpenting dalam membentuk mental, kepribadian dan jiwa sehingga mampu mengarahkan serta mengkontrol keberanian dan emosi mereka. Pola yang terjadi adalah, laskar mantan preman mengadakan halaqoh yang berisi tentang pentingnya amar ma'ruf nahi mungkar kemudian langsung praktek di lapangan. Di daerah yang telah ditaklukan, ustad Sigit selaku komandan mengadakan pengajian dan membuka perekutan anggota baru kemudian diajak langsung beraksi. Hal ini menjadi daya tarik bagi sebagian preman yang takut pada laskar untuk bergabung dengan kekuatan baru ini. Secara umum, Ustad Sigit melaksanakan kegiatan nahi mungkar pada hari Sabtu malam Ahad. ${ }^{10}$ Jadi proses pembentukan identitas hanya pada proses ta'rif dan tanfidz.

Jum'ah Amin Abdul Aziz menyatakan bahwa sebagian besar umat Islam kehilangan kepribadian sebagai seorang muslim. Dia berpendapat bahwa ajaran Islam mendahulukan tarbiyah (pembinaan) sebelum tasyri' (pemberlakuan hukum), Risalah Islam merupakan risalah akhlak sebelum jihad, risalah kemuliaan dan nilai sebelum menjadi banyak dan tersebar luas. Maka dia menyimpulkan bahwa inti ajaran Islam adalah akhlak dan ihsan, sarananya keteladanan, dan objeknya adalah jiwa. ${ }^{11}$ Pandangan Jum'ah terhadap Islam ini yang berkebalikan pada diri laskar mantan preman. Mereka memaksakan penerapan syari'at sebelum proses pembinaan, mendahulukan jihad sebelum mempelajari dan mendalami akhlak Islam, sehingga muncul di lapangan, perkataan-perkataan sebagian anggota laskar yang kasar, kotor atau bahkan kekerasan dalam upaya melakukan nahi mungkar.

Salah satu pendorong terpenting perubahan preman menjadi ikhwan kemudian laskar adalah mencari makna hidup dan kebermaknaan sosial. Pendorong dari pencarian makna hidup ini adalah faktor ekonomi dan ketidak jelasan sosial politik. ${ }^{12}$ Dalam konteks laskar, kegiatan kelaskaran dalam berdemo dan melakukan nahi mungkar merupakan alat mencari makna hidup dan kebermaknaan sosial. Mereka merasa bangga menjadi bagian dari kelompok yang dikategorikan Nabi Muhammad SAW sebaik-baik amal. Dalam bayangan

\footnotetext{
${ }^{8}$ Noorhaidi Hasan, Laskar Jihad: Islam, Militansi, Dan Pencarian Identitas Di Indonesia Pasca OrdeBaru, 2.

${ }^{9}$ Musthafa Masyur, Fiqih Dakwah, Kedua (Jakarta: Al-I'tishom Cahaya Umat, 2001), 14-15.

${ }^{10}$ Warsito, Preman Taubat, Pertama (Al Aqwam, 2016), 107.

${ }^{11}$ Jum'ah Amin Abdul Aziz, Fiqih Dakwah (Solo: Era Intermedia, 2000), 73.

12 Gazi Saloom, "Jihad Dan Thầifah Manshûrah: Basis Syariah Identitas Kelompok Jihadis," AHKAM: Jurnal Ilmu Syariah 16, no. 1 (2016).
} 
anggota, setiap aksi nahi mungkar sebagai jihad. Mereka meyakini bahwa meninggal dalam aksi konfrontasi dengan para preman sekuler sebagai syahid.

Para ahli teori sosial menyebut bahwa bergabungnya satu individu ke dalam suatu kelompok pergerakan dan menginternalisasikan idenditas kelompok kedalam dirinya sehingga motivasi, pemikiran dan penafsiran kelompok lebih kuat dari motivasi diri sendiri sebagai identitas sosial. Selama motivasi kelompok lebih besar, maka anggota akan tetap bergabung dalam kelompok tersebut tetapi ketika motivasi diri lebih besar daripada motivasi kelompok maka ia akan keluar dari jaringan kelompok tersebut. ${ }^{13}$ Teori ini bisa mengalisa sebab kenapa para anggota laskar mau keluar di malam hari untuk melakukan nahi mungkar di saat manusia secara umum tidur di rumah. Hal ini karena motivasi laskar untuk keluar di malam hari mengalahkan keinginan anggota untuk tidur di rumah atau bercanda dengan anggota keluarga. Pada kelompok sejenis laskar, kualitas seorang pemimpin menjadi memiliki peran sentral dalam menjalankan kelompoknya. Hal ini terbukti, ketika seorang pemimpin laskar (Sigit Qardawi) meninggal, dan tidak ada seorang yang memiliki kualitas seperti pemimpin pertama ini, maka laskar terpecah dan sebagian besar anggota berhenti.

Teori identitas sosial memiliki empat mekanisme. Pertama adalah ketegorisasi kelompok. Ini merupakan langkah pertama dimana orang mengkategorisasi dirinya dan orang lain dalam kelompok yang berbeda. Kedua adalah perbandingan sosial. Ini merupakan mekanisme orang membandingkan apa yang dilakukan kelompoknya dan apa yang telah dilakukan kelompok lain. Ketiga adalah identifikasi kelompok. Hal ini berupakan kesadaran bergabung dengan kelompok karena telah memahami kelompoknya. Hal ini menyebabkan dirinya bangga menjadi bagian dari kelompoknya. Keempat adalah distingsi ingroup. Langkah ke-empat yang berupa keyakinan bahwa kelompoknya lebih baik dan merendahkan kelompok yang lain. ${ }^{14}$ Mekanisme-mekanisme ini terjadi dalam dunia laskar. Pertama-tama mereka mengelompokan diri sebagai muslim atau tidak muslim, bahkan antara muslim yang benar atau muslim yang salah. Kemudian untuk menumbuhkan militansi kelompok, diberitakan hal-hal yang telah dilakukan kelompok musuh yang jika laskar tidak bertindak maka mereka akan kalah. Mekanisme ketiga meyakini bahwa mereka berada dalam lingkungan dan kelompok yang benar. Kisah korban penembakan densus yang jasadnya berbau harum menambah keyakinan mereka. Terakhir berupa menganggap kelompok yang lain lebih rendah.

Proses penting kedua dalam penanaman identas laskar adalah ideologisasi jihad. Jihad yang dalam beberapa redaksi hadist Nabi memiliki beberapa makna seperti nasehat yang benar kepada pemimpin yang dzalim, ${ }^{15}$ berbuat baik kepada orang tua sebagaimana kisah seorang pemuda yang dating kepada Nabi Muhammad SAW memohon izin untuk berjihad kemudian Nabi menanyakan tentang kedua orangtua pemuda itu apakah masih hidup, ketika pemuda itu menjawab masih hidup, maka Nabi Muahammad SAW menyatakan

\footnotetext{
${ }^{13}$ Saloom.

${ }^{14}$ Gazi Saloom, "IDENTIFIKASI KOLEKTIF DAN IDEOLOGISASI JIHAD," Jurnal Dialog 38, no. 1 (2015): 1-12.

${ }^{15}$ HR Abu Dawud no. 4344 "sebaik-baik jihad adalah perkataan yang benar didepan pemimpin yang dhalim"
} 
bahwa jihad pemuda itu berupa memelihara orangtua yang sudah lanjut usia tersebut, ${ }^{16}$ jihad bagi wanita adalah menunaikan ibadah haji dan umrah, ${ }^{17}$ Nabi juga memberikan gelar kepada wanita yang meninggal dunia ketika melahirkan anak, ${ }^{18}$ atau jihad berarti sungguhsungguh dalam beribadah. ${ }^{19}$ Makna jihad yang banyak ini dimonopoli dengan satu makna jihad berarti perang. Memonopoli makna jihad ini yang disebut ideologisasi jihad. ${ }^{20}$ Dalam dunia laskar, para pimpinan menganologikan nahi mungkar sebagai jihad karena memiliki potensi yang mirip berupa bentrok dengan pelaku kemaksiatan. Selain penganologikan nahi mungkar dengan jihad, pimpinan juga menanamkan keutamaan nahi mungkar seperti keutamaan jihad seperti melakukan sebaik-baik amal, syahid bagi yang meninggal dalam melakukan aksinya dan dimaafkan dosa-dosanya. Ideologisasi jihad ini yang membuat sebagian laskar merasa lebih utama daripada orang-orang yang berilmu dan taat ibadah tetapi tidak melakukan nahi mungkar.

\section{Dialeksisasi Identitas Lama dengan Identitas Baru}

Habitus merupakan hasil dari perilaku individu dalam suatu masyarakat yang berulang-ulang sehingga mempengaruhi pemikiran, penafsiran dan perilaku seseorang. Habitus bertahan lama dan sulit berubah. ${ }^{21}$ Sifat dan kepribadian preman yang sudah menyatu dalam diri selama bertahun-tahun menjadi tantangan para preman yang bertaubat untuk menegosiasikan pemikiran, penafsiran dan perilaku premanisme ke dalam identitas yang baru dan berlainan. Premanisme muncul karena desakan ekonomi dan sebagai usaha bertahan hidup di kota bagi mereka yang tidak bisa bersaing merebutkan kue ekonomi secara normal. Mereka hidup keras di jalan, memiliki keinginan untuk menang, tidak terbiasa bermusyawarah. ${ }^{22}$ Sehingga saya berpendapat bahwa dunia laskar adalah proses negosiasi dalam diri preman taubat menyalurkan naluri dunia preman yang keras dalam identitas baru sebagai muslim. Laskar yang merupakan paralimiter Islam yang bertujuan menegakkan syari'at Islam dan memerangi kemaksiatan dengan melakukan sweeping tempat hiburan, pelacuran, main judi dan berbagai kegiatan kemungkaran yang lain ${ }^{23}$ diyakini sebagai jihad yang merupakan tingkatan amal yang tertinggi. Proses negosiasi identitas lama ke dalam identitas baru generasi awal preman taubat mengalami tiga fase

\footnotetext{
${ }^{16}$ HR Ahmad no. 6765 "maka pada keduanya, jihad kamu"

${ }^{17}$ HR Ibnu Majah no.2901 "Wahai Rasulullah, apakah ada jihad bagi wanita?" Beliau menjawab, "Jihad yang tidak ada peperangan di dalamnya, yaitu haji dan umrah."

${ }^{18}$ HR Ahmad no. 15998 "padahal orang yang terbunuh di jalan Allah Azzawajalla adalah syahid, orang yang mati terkena wabah adalah syahid, orang mati tenggelam adalah syahid, orang yang mati karena sakit perut adalah syahid, wanita yang meninggal karena melahirkan anaknya, anaknya menariknya dengan tali pusar untuk masuk ke surga"

${ }^{19}$ HR Ibnu Hiban no. 4862 “... . Adapun seorang mujahid adalah orang yang bersungguh-sungguh dalam menundukkan hawa nafsunya dalam melaksanakan ketaatan kepada Allah ...."

${ }^{20}$ Saloom, "IDENTIFIKASI KOLEKTIF DAN IDEOLOGISASI JIHAD."

${ }^{21}$ Haryatmoko, Membongkar Rezim Kepastian: Pemikiran Kritis Post-Strkturalis (Yogyakarta: PT Kanisius, 2016), 41.

${ }^{22}$ Wasisto Raharjo Jati, "Kuasa Dan Kekerasan: Kelembagaan Premanisme Yogyakarta Paska Reformasi," Jurnal Sosiologi Islam 2, no. 1 (2012): 61-76.

${ }^{23}$ Noorhaidi Hasan, Laskar Jihad, 2.
} 
Fase pertama adalah fase kesadaran preman untuk mengubah pemikiran dan perbuatan mereka. Pada periode ini, muncul kesadaran diri yang distimulus oleh dakwah menjadi muslim yang baik dan dorongan keluarga. Pada periode ini keislaman mereka sebagaimana digolongkan Ibnu Katsir sebagai dholimul linafsih. ${ }^{24}$ Mereka melakukan kewajiban-kewajiban Islam tetapi mereka tidak mampu meninggalkan hal-hal yang diharamkan oleh Allah. Pada fase ini, pengaruh habitus masih nampak dalam praktek kehidupan sehari-hari. Sebagian mereka berpuasa di siang hari di bulan Romadhon, tetapi mabuk-mabukan di malam harinya. Sebagian mereka melakukan sholat wajib tetapi setelah bergabung dengan teman-teman mereka yang belum sadar, mereka berjudi, minum khomer, dan melakukan tindakan asusila kembali.

Tokoh penting dalam periode ini adalah ustad Andi LC. Seorang da'i putra dari pendiri Majlis Tafsir Al-Qur'an Ust Abdullah Thufail lulusan al- Azhar Mesir. Pada periode ini, beliau menyatakan bahwa metode dakwahnya sebagaimana dakwah Nabi Muhammad SAW di massa Makkah. Dia hanya mengajak preman-preman untuk mendatangi majlis taklim meskipun dalam keadaan mabuk. Materi yang diajarkan pada periode adalah adab, tazkiyatun nafs (pensucian diri) dan aqidah Islam. Dia menghindari masalah khilafiyah baik fikih maupun aqidah. Untuk meredam naluri preman yang keras dan melatih kesabaran mantan preman, Ust Andi meminta mereka untuk khuruj mengikuti jamaah tabligh. Mereka merasa betapa sulitnya menahan emosi ketika mengetuk rumah orang untuk mengajak sholat ke masjid tetapi justru dimarahi. ${ }^{25}$ Mereka merasa izzah sebagai muslim tidak ada, tetapi hal ini tetap dilakukan sampai mereka berjumpa ust haroki dalam fase kedua.

Fase kedua adalah fase perjumpaan mantan preman dengan ustadz-ustadz pergerakan yang melakukan pembentukan muslim yang berjuang menegakkan syari'at Islam. Materi utama kajian pada fase ini adalah wala' wal bara'. Proses mengkategorisasikan orang sebagai teman dan lawan, siapa yang layak diangat sebagai pemimpin dan siapa yang harus dilawan, siapa yang harus dicintai dan siapa yang dibenci. Wala atau kesetiaan, persahabatan, kepemimpinan diberikan kepada seorang muslim yang mau menegakan syari'at Islam sementara bara' atau permusuhan diberikan kepada orang-orang yang menolak syari'at Islam. Pada fase ini, mereka mulai mengambil jarak dengan pemerintahan yang mereka anggap sebagai thogut (orang yang tidak berhukum dengan hukum Allah) dan semua lembaga pemerintahan sampai dengan lurah. Mereka juga melihat pelaku maksiat sebagai pendosa besar yang harus dibubarkan. Hal ini menjadi pintu masuk gerakan laskar di daerah Semanggi Surakarta. Habitus yang muncul dalam periode kedua adalah adanya ajaran agama yang mengakomodasi sifat keras mereka.

Karakteristik keislaman preman yang sadar adalah berusaha menjadi muslim yang baik dan ikut dalam gerakan keagamaan yang menuntut komitmen yang tinggi, kesukarelaan dan semangat pada orientasi merasa terlahir kembali sebagai muslim sejati. Keislaman mereka yang terlambat dan bergabung dalam haroki membuat pemahaman keislaman mereka kaku. Guru-guru mereka memberi pilihan hitam atau putih, dan menjelaskan akibat dari penolakan ajaran Islam adalah kafir. Pola keagamaan seperti ini merupakan tempat

\footnotetext{
${ }^{24}$ Abu Fida Ibnu Katsir, Tafsir Al-Qur'an Al-Adhim (Beirut: Darul Fikri, 1997), Juz ketiga Hal 579.

${ }^{25}$ Warsito, Preman Taubat, 2016, 84.
} 
perlindungan bagi umat Islam yang telah melakukan hijrah internal untuk melindungi diri dari noda dan godaan dunia luar. ${ }^{26}$

Pada fase ini, mereka mulai membedakan ustadz yang berani dan tegas terhadap pemerintah serta berani terjun ke kegiatan kelaskaran, dengan ustadz yang membahas keilmuan keislaman, seperti fikih, tarikh, adab dan materi lain yang tidak berhubungan dalam dunia laskar. Mereka memuji ustadz di kelompok pertama dan meremehkan tipe ustadz yang kedua. Selain itu, sikap mereka kepada pelaku kemaksiatan jelas, mencegah pelaku maksiat dengan kekuatan fisik yang mereka anggap mampu. Kebijakan ini terinspirasi hadist Nabi Muhammad SAW yang diriwayatkan Imam Ahmad dari sahabat Abu Sa'id al Khudri "barang siapa melihat kemungkaran, hendaknya dia mencegahnya dengan tangannya, apabila tidak mampu dengan tangannya, hendaknya dia mencegahnya dengan mulutnya, apabila tidak mampu, hendaknya dia mengingkari kemaksiatan itu dengan hatinya, dan hal itu adalah selemah-lemah iman". ${ }^{27}$ Untuk itu, kegiatan nahi munkar bergerak dengan masif dan beberapa kantong desa preman menjadi desa yang bebas dari miras dan judi yang dilakukan secara terang-terangan. Desa-desa itu adalah Sangkrah, Losari, Semanggi, dan Kusomodilagan.

Dalam praktek amar ma'ruf nahi munkar mereka lebih fokus pada kegiatan nahi munkar daripada amar ma'ruf. Untuk itu, praktek nahi munkar sering mengutamakan kekuatan fisik dan keinginan menundukkan preman daripada dakwah. Dalam melakukan nahi munkar pimpinan laskar memberi tiga pilihan kepada pelaku kemunkaran, yakni, taubat, berhenti, atau perang adu fisik dengan laskar. ${ }^{28}$ Di awal tahun $2000 \mathrm{an}$, ketika laskar juga masih baru dan kekuatan mereka belum teruji, para preman memilih perang adu fisik dengan laskar, bahkan di bebarapa kejadian, mereka yang memantik kejadian untuk berkonfrontasi dengan laskar. Contoh-contoh adu fisik antara laskar dan preman antara lain Waru Doyong Solo Baru 2005, Kusumodilagan, Gandekan, dan Losari. Terjadi pergeseran kekuatan nonformal di masyarakat dari preman sekuler ke laskar.

Secara amaliyah dhohir, keislaman mantan preman pada fase kedua ini masuk dalam tipologi kedua umat Islam yang disarikan Ibnu Katsir sebagai muslim muqtasid. Mereka muslim yang melakukan kewajiban-kewajiban Islam dan mampu meninggalkan dosa-dosa besar seperti judi, mabuk, dan perzinaan tetapi masih melakukan hal-hal yang makruh. ${ }^{29}$

Fase ketiga adalah fase pasca meninggalnya tokoh utama laskar HISBAH yang memimpin laskar di Semanggi Sigit Qardawi. Sigit Qardawi yang menjadi target operasi densus 88 meninggal pada Sabtu 15 Mei 2011. Dia tertembak di ujung gang Jalan Palagan Tentara Pelajar, desa Sanggrahan, Grogol, Kabupaten Sukoharjo, Jawa Tengah. ${ }^{30}$ Tim Hisbah pecah menjadi beberapa Komando yang memiliki kebijakan berbeda antara satu komando dengan komando yang lain. Secara hireaki struktur dan wasiat dari Sigit Qardhawi,

\footnotetext{
${ }^{26}$ Noorhaidi Hasan, Laskar Jihad, 229-45.

${ }^{27}$ Hadist No 11460 Ahmad bin Hambal, Musnad Al-Imam Ahmad Bin Hambal (Beirut: Muasasah ar-Risalah, 2001), Juz 18, hal 42.

${ }^{28}$ Warsito, Preman Taubat, 2016, 111.

${ }^{29}$ Abu Fida Ibnu Katsir, Tafsir Al-Qur'an Al-Adhim, Juz Ketiga, Hal 579.

30 Umat Islam Bongkar Kejahatan Densus 88 Di Muka FKPT, accessed September 28, 2018, https://www.tribunislam.com/2014/09/umat-islam-bongkar-kejahatan-densus-88-di-muka-fkpt.html.
} 
Agus Junaidi menjadi penerus resmi tim Hisbah. ${ }^{31}$ Tetapi naluri preman yang tidak mau tunduk dan memberontak pada orang yang kurang dihargai meskipun secara hireaki kepemimpinan dia layak memimpin. Habitus preman yang nampak pada periode ketiga adalah logika preman yang ingin menang dan tidak siap menerima perbedaan.

Setelah Sigit Qardawi meninggal, laskar terpecah menjadi beberapa komandan yang memiliki kebijakan yang berbeda. Secara umum, saya membagi mereka menjadi laskar kamuflase dan laskar moderat. Saya menduga perbedaan laskar ini dipengaruhi perbedaan motif mereka masuk ke dalam laskar. Sebagaimana disinggung sebelumnya, preman bergabung dengan laskar karena tiga alasan, takut, hilang pamor, dan ketulusan hati atau hidayah. Pada fase ini, preman yang bergabung dengan laskar karena alasan takut atau hilang pamor menampakan realitas dan mental preman mereka. Sebagian laskar kamuflase kembali ke dunia preman sebagai penjaga keamanan tempat hiburan, ${ }^{32}$ sebagian menjadi debt collector, sebagian lagi bermain dengan kotor dalam lembaga finance, sebagai contoh mereka mengajukan pembelian motor atau mobil ke lembaga finance, setelah motor atau mobil dating mereka menjual motor atau mobil itu. Debt collector yang kebanyakan seorang preman tidak berani menagih kekurangan pembayaran. Motif yang lain adalah kerjasama antara oknum laskar dengan petugas finance untuk mencairkan permohonan pembelian. Setelah mobil dijual, uang dibagi-bagi antara pelaku dan pegawai lembaga finance.

Penguasaan kapital ekonomi menjadi prioritas utama dalam gerakan laskar kamuflase. Mereka menggunakan logika preman dengan simbol dan bahasa laskar untuk mencapai pendapat kapital ekonomi ini. Logika preman berupa kekerasan dan kekuatan fisik untuk mengambil hak milik orang lain secara paksa dengan menggunakan istilah-istilah Islami. Ketika mereka melakukan sweeping perjudian, sebagian mereka mengambil uang judi itu sebagai $\mathrm{fa}^{\prime} \mathrm{i}^{33}$ atau hasil rampasan milik orang kafir. Sebagian mengambil helm milik orang pacaran yang mereka sweeping. ${ }^{34}$

Penggunaan kata kamuflase ini untuk menggambarkan sebuah kenyataan yang tidak asli. Jadi Laskar kamuflase adalah laskar yang menggunakan kata, penampilan, dan simbolsimbol Islam tetapi mereka melakukan kegiatan premanism. Laskar kamuflase mengalami perubahan dalam beberapa variasi, yakni perubahan bentuk, rupa, war na, dan hal lainnya supaya tidak dikenali. Penggunaan kamuflase untuk menggambarkan adanya perubahan preman dalam bersikap dan penampilan dengan meninggalkan identitas preman menjadi laskar tetapi perubahan itu tidak pada pokok inti keislaman.

Tipologi laskar yang kedua adalah laskar moderat. Mereka merupakan mantan anggota preman kemudian sadar akan kesalahan masa lalu mereka dan berkeinginan memperbaiki diri. Kegiatan laskar mereka berdasarkan satu niatan untuk membersihkan lingkungan mereka dari hal-hal yang bersifat destruktif. Penulis menyebut mereka sebagai moderat karena mereka bergabung dalam laskar dan bertindak sesuai batas-batas dalam Islam

${ }^{31}$ Muhammad In'am Esha, "KEPEMIMPINAN DI ERA DEMOKRASI DELIBERATIF," ElQUDWAH, 2014.

${ }^{32}$ Nur Kafid, "Dari Islamisme Ke 'Premanisme': Pergeseran Orientasi Gerakan Kelompok Islam Radikal Di Era Desentralisasi Demokrasi," MASYARAKAT: Jurnal Sosiologi, 2016, 57-79.

${ }^{33}$ Wahbah al-Zuhayly, Al-Figh Al-Islami Wa Adilatuh (Damaskus: Darul Fikri, 1989), 455.

${ }^{34}$ Warsito, Preman Taubat, 2016, 137. 
dan tidak berlebih-lebihan. Perbedaan nyata dengan kelompok kamuflase adalah pemanfaatan laskar untuk kepentingan pribadi. Salwa Ismail menyebut proses penyadaran diri dan keinginan menjadi muslim yang baik dengan melakukan hal-hal yang berat seperti bangun malam untuk sholat tahajud sebagai "objectification" sementara Beck dan Gidden menyebutnya sebagai "self-relexivity"35

Perbedaan pada laskar moderat dengan kamuflase adalah para laskar moderat ini bisa menerima pendapat berbagai ustad. Mereka tidak mengkhusus pada ustad tertentu. Hal ini menjadikan laskar moderat lebih bijaksana dalam pengambilan keputusan dan pergerakan. Pada proses amar ma'ruf nahi mungkar, mereka tetap menjaga diri dari harta milik pelaku kamaksiatan yang mereka tangkap. Bahkan mereka tetap menawarkan pembinaan keislaman kepada preman yang ditaklukan. Proses pembinaan yang utama dilakukan preman yang sudah ditundukan adalah kesanggupan untuk sholat berjamaah lima waktu di masjid. Jika rumah preman tersebut dekat dengan markaz mereka, mereka menuntut preman tersebut untuk sholat di masjid markaz, tetapi jika rumah preman taubat tersebut jauh dari markaz, komandan laskar meminta preman yang telah taubat terlebih dahulu untuk mengawasi dan memberi laporan. ${ }^{36}$

\section{Islamisme, Kesalehan aktif dan Kesalehan Pasif}

Islamisme merupakan istilah pergerakan aktivis muslim yang terakhir. Sebelum nama ini, ada fundamentalism, kemudian digantikan dengan istilah "islamic movement,' 'political Islam', 'Islamic Activism', Islamic revivalism', or 'resurgence' dan 'new religious politic'. Meskipun beberapa sarjana telah memberikan beberapa istilah gerakan sosial Islam ini, Asef berpendapat bahwa inti dari beberapa nama ini mengacu pada tema yang sama yaitu, gerakan aktivis keagamaan. Dalam penelitiannya, Bayat menyatakan bahwa penekanan pada gerakan ini pada kata aktivis. Ketika orang mempraktekan ajaran agama dengan taat tetapi dia tidak berusaha mengajak orang untuk mengamalkan ajaran agama, maka orang seperti ini tidak bisa disebut aktivis, orang seperti ini banyak di Mesir, baik beragama Islam maupun Kristen. Jadi aktivis adalah orang yang aktif dalam menjalankan ajaran agama tetapi dia ingin supaya orang menjalankan ajaran agama seperti dia menjalankannya. Bayat kemudian membedakan istilah islamisme untuk pergerakan aktivis agama yang bertujuan untuk mengganti system pemerintahan dengan system Islam sementara kesalehan yang aktif menunjukan orang yang taat pada agama dan berharap serta mengajak orang untuk menjalankan perintah agama tetapi tidak berambisi mengambil alih pemerintahan. ${ }^{37}$

Istilah active piety milik Asef Bayat ini selaras dengan Poliyic Piety atau politik kesalehan yang ditawarkan Saba Mahmood. Mahmood menjelaskan pergerakan tiga masjid yang digerakan aktivis perempuan. Gerakan tiga masjid itu, selain mengajarkan nilai-nilai Islam juga mengadakan pelatihan-pelatihan yang bermanfaat untuk wanita-wanita yang

${ }^{35}$ Salwa Ismail, "Being Muslim: Islam, Islamism and Identity Politics," Government and Opposition 39, no. 4 (2004): 614-31.

${ }^{36}$ Warsito, Preman Taubat, 2016, 140.

${ }^{37}$ Asef Bayat, "Islamism and Sosial Movement Theory," Third World Quarterly 26, no. 6 (2005): 891908. 
mengikutinya. Saba Mahmood juga menjelaskan bahwa gerakan kesalehan ini tidak mengarah pada pengambil alihan pemerintahan sah tetapi gerakan yang berorientasi pada pemberdayaan wanita muslim baik dalam kegiatan keagamaan maupun traning-traning kewirausahaan. ${ }^{38}$

Pembahasan Islamism selalu menempatkan Islam sebagai faktor penentu, sebuah keyakinan yang tidak berubah dan sebuah wacana yang menggerakan pemeluknya untuk melakukan sesuatu yang mereka yakini sebagai perintah yang harus ditaati. Para islamis meyakinan bahwa kehidupan mereka harus selaras dengan apa yang dilakukan pendahulu agama ini. Pola keyakinan ini mendorong para aktivis islamis untuk berbuat sesuatu meskipun bertentangan dengan norma yang ada dalam masyarakat bahkan negara. Usaha menyelaraskan kehidupan lingkungan dengan ajaran Islam ini yang menjadi agenda kaum islamis. Sebagian mereka bercita-cita mengubah dasar negara dan mengambil alih pemerintahan sementara sebagian yang lain hanya fokus pada penerapan ajaran Islam dalam kehidupan sehari-hari yang tidak bermaksud mengambil alih pemerintahan. Contoh model gerakan yang kedua ini adalah menjalan ekonomi syari'ah dalam kehidupan mereka. ${ }^{39}$

Gerakan islamism pada dasarnya sebuah aksi melawan dominasi sekuler Barat di dunia Islam. Perlawanan ini muncul karena kegagalan pemerintah memberi kesejahteraan pada rakyatnya. Untuk itu, mereka ingin penegakan sya ri'at Islam sebagai solusi terhadap masalah sosial, ekonomi dan pendidikan. Di dunia timur tengah, gerakan islamism muncul dengan berdirinya ikhwanul muslimin oleh Imam Hasan al-Bana. Pelaku gerakan Islamism terbagi menjadi tiga kelompok, militan, konservatif dan moderat. Kelompok militan terdiri dari masyarakat kelas menengah ke bawah. Mereka biasa melakukan aksi fisik dan kekerasan dalam menjalankan misinya. Sementara konservasif berasal dari kelompok menengah ke atas. Mereka melakukan perjuangan dengan mengajarkan nilai-nilai moral Islam dan gerakan ekonomi syari'ah. Moderat menjalankan gerakannya dengan bergabung dalam pemerintahan. Mereka bekerja sebagai profesional atau masuk dalam partai atau pemerintahan..$^{40}$

Tholhah Hasan menyebut kelompok yang menyakini Islam telah sempurna dan berupaya menegakkan syari'at dalam beragama dengan sebutan fundamentalis. Kelompok ini memiliki slogan-slogan, antara lain; pertama, seruan kembali kepada Al-Qur'an dan As Sunnah yang dipandang sebagai ajaran yang lengkap untuk semua bidang (Ar-Ruju' ilal Qur'an was sunnah). Kedua, Mendirikan Negara Islam sebagai tujuan akhir perjuangan. Pandangan ini menetapkan bahwa politik dan agama adalah bagian mutlak dari totalitas Islam. (Al-Islam dienun wa daulatun). Ketiga, Tradisi yang benar adalah islam, semua tradisi yang bukan berdasarkan Islam adalah salah (Fama ba'dal Haqqi illa dlolal). Ke-empat, Kebudayaan barat dipandang sebagai musuh islam, dan orang-orang yang sudah terpengaruh dengan pemikiran Barat dianggap berbahaya. Kelima, klaim kebenaran untuk kelompoknya,

${ }^{38}$ Saba Mahmood, Politics of Piety: The Islamic Revival and the Feminist Subject (Princeton University Press, 2011).

${ }^{39}$ Ismail, "Being Muslim: Islam, Islamism and Identity Politics."

${ }^{40}$ Ismail. 
sehingga sulit mengakomodasikan pemikiran orang lain meskipun dari kalangan umat islam. mereka sering memvonis kelompok lain "sesat" bahkan "kafir". ${ }^{41}$

Secara umum, gerakan Islamisme di Indonesia pasca jatuhnya president Soeharto bisa dibagi menjadi tiga, gerakan Islamisme ideologis, puritan dan kesalehan popular. Gerakan Islamisme ideologis ini terdiri dari kelompok jihadis, tarbawi dan tahriri. Untuk jihadis ini secara umum import dari gerakan jihadis trans-nasional seperti, Abdullah Azzam, Usamah bin Laden, Najih Ibrohim dan lain-lain. Gerakan jihadis menekan pentingnya menumbuhkan dan menjaga ruh jihad dalam diri umat Islam. Karena tanpa jihad, wibawa agama Islam akan hilang. Sementara gerakan tarbawi berakar dari gerakan ikhwanul muslimin dari Mesir. Tokoh-tokoh gerakan tarbawi di Indonesia antara lain Rahmat Hidayat, Anis Mata dan penulis buku-buku tarbawi terkenal Salim A. Fillah. Berikutnya adalah gerakan Islamisme tahriri. Kelompok pergerakan ini memproduksi wacana khilafah sebagai solusi kerusakan moral, pemerintahan dan budaya. Gerakan ini didirikan oleh Taqiyuddin Nabhani di plestina pada tahun 1951. Meskipun telah dilarang di Indonesia pada 2017, agen-agen hizbut tahrir tetap exis. Salah satu dari mereka adalah felix shau yang aktif berdakwah dan menulis dengan tema tahriri. ${ }^{42}$

Gerakan keagamaan laskar memperjuangkan tegaknya syari'at Islam tetapi mereka tidak menolak modernitas. Mereka tetap mengikuti perkembangan teknologi HP, kendaraan bermotor, atau tehnologi informatika. Mereka juga secara aktif membuat group-group di Whatsapp untuk sarana berkomunikasi, mengunakan facebook sebagai media untuk membagikan informasi atau melihat you tube untuk mengikuti berita atau mendengar ceramah. Jadi gerakan laskar bukan gerakan anti modernitas tetapi mereka menolak system pemerintahan Barat (demokrasi), kebebasan yang mutlak, serta serbuan budaya yang berlawanan dengan nilai Islam dan timur seperti sex bebas. Penolakan terhadap demokrasi ini mereka lakukan dengan tidak mau mengikuti pemilihan umum, pilgub, ataupun pilkada. Sebagian anggota laskar yang ekstrem bahkan mengkafirkan orang-orang yang mengikuti pemilu. Jadi, atas nama demokrasi mereka menuntut kebebasan mengekspresikan pendapat tentang dukungan terhadap syari'at Islam, tetapi atas nama kemurnian syari'at Islam mereka menolak demokrasi. Berdaarkan tepologi gerakan Islamisme di Indonesia, gerakan laskar masuk ke dalam gerakan Islamisme Ideologi jihadis.

\section{Imagined common enemy}

Asef Bayat mengajukan sebuah teori Imagined Solidarity yang menjelaskan bagaimana sebuah bayangan solidaritas yang sama mampu membentuk sebuah kegiatan kolektif. Gagasan ini bermula dari realitas kelompok-kelompok Islamisme yang terpecah menjadi berbagai organisasi dan aliran tetapi dalam beberpa hal bisa melakukan kegiatan bersama dan bisa bekerja sama. Untuk mengilustrasikan hal ini, Asef menjelaskan bahwa

\footnotetext{
${ }^{41}$ Muhammad Tholhah Hasan, Prospek Islam Dalam Menghadapi Tantangan Zaman, ke-lima (Jakarta Selatan: Lantabora Press, 2005), 76.

${ }^{42}$ Munirul Ikhwan, "Produksi Wacana Islam(Is) Di Indonesia," in Literatur Keislaman Generasi Milenial; Transisi, Apropriasi, Dan Kontestasi (Yogyakarta: Pasca Sarjana UIN Sunan Kalijaga Press, 2018), 63108.
} 
perbedaan ini dipicu oleh dua sumber, yakni; perbedaan kepentingan dan perbedaan dalam penafsiran. Maka salah satu yang dapat menyatukan gerakan mereka adalah "solidaritas yang terbayang". ${ }^{43}$ Kelompok islamisme ini memiliki bayangan dalam pemikiran mereka dengan persepsi yang sama. Bayangan solidaritas atas penyerangan Amerika atas Iraq membuat orang-orang di berbagai belahan dunia melakukan demontrasi khususnya di Negara-negara Islam.

Kehidupan laskar yang memiliki hubungan erat dengan kekerasan fisik sulit untuk diajak bekerjasama dalam wacana ukhuwah apalagi jika mereka merasa bahwa kelompoknya yang lebih benar dari yang lain. Ini menjadi PR para pemimpin agama di Solo dimana identitas sosial itu masih berupa perasaan bersama dalam satu komunitas kecil dan belum berupa satu ummah. Sehingga dorongan ukhuwah Islam sebagai perwujudan ummah belum mampu menjadi motivasi identitas sosial di kelompok laskar atau lembaga-lembaga Islam. Tetapi dalam beberapa kasus kejadian, umat Islam khususnya di Solo bisa membuat satu kumpulan besar sebagai lambang persatuan, salah satunya adalah parade Tauhid pada 16 Mei 2015. ${ }^{44}$ Meskipun untuk segala macam perizinan, parade tauhid ini bertujuan menyambut bulan Ramadhan, tetapi motivasi lain penyelenggaraan parade ini adalah bentuk respon dari diselenggarakannya parade salib pada 29 April 2015.45 Sesuai dengan teori ini, saya yakin bahwa wacana yang dibangun di masyarakat bahwa orang-orang Kristen di Solo sudah semakin berani dengan mengadakan parade salib menjadi pendorong utama kedatangan para peserta dibanding parade tauhid dengan wacana menyambut bulan Ramadhan.

Untuk menumbuhkan rasa pembelaan terhadap Islam dan mental jihad, diwacanakan sebuah musuh bersama (imagined common enemy) yang digambarkan sudah dekat dan bahkan menguasai sendi-sendi kehidupan kaum muslimin. Musuh itu digambarkan ingin menghancurkan Islam, menjauhkan umat Islam dari ajaran agamanya dan melemahkan kekuatan ekonomi dan politiknya. Untuk mempertahankan keberadaan agama ini, maka mereka harus berjihad dan mempertahankan Islam bahkan memperjuangkannya menjadi menang. ${ }^{46}$

Keberhasilan GNPF (Gerakan Nasional Pengawal Fatwa) mewacanakan Ahok yang dilindungi penguasa dan didukung pengusaha-pengusaha besar tanah air sebagai orang yang menistakan al-Qur'an mampu mendatangkan tujuh juta orang berkumpul dalam satu tempat dan menyuarakan tuntutan yang sama, hukum penista agama. ${ }^{47}$ Ketika di Monas, saya merenung bagaimana berbagai ormas dan laskar yang tidak bisa disatukan dengan isu ukhuwah atau tolenrasi dalam perbedaan fikih bisa bersatu dan duduk bersama di satu tempat. Dalam kehidupan sehari-hari, laskar yang rata-rata binawaan gerakan bawah tanah

${ }^{43}$ Asef Bayat, "Islamism and Sosial Movement Theory," Third World Quarterly 26, no. 6 (2005): 891908.

${ }^{44}$ https:/www.panjimas.com/news/2015/05/17/ratusan-ribu-umat-islam-banjiri-jalan-slamet-riyadisolo-dalam-acara-parade-tauhid/

45 https://www.panjimas.com/news/2015/05/18/kh-wahyudin-saya-dukung-parade-tauhid-agarumat-islam-tidak-minder-dengan-adanya-parade-salib/

${ }^{46}$ Munirul Ikhwan, "Produksi Wacana Islam(Is) Di Indonesia."

47 https://www.hidayatullah.com/artikel/ghazwul-fikr/read/2016/12/08/107231/aksi-212-dan-5fenomena-lahirnya-generasi-baru-islam-indonesia.html 
jihadis sangat anti dengan istilah haul, majlis Rasulullah, sholawatan bersama-sama atau sebaliknya orang-orang yang tergabung dalam habaib di Solo yang tidak setuju dengan aksi laskar, mereka bisa berkumpul dan tidak mempermasalahkan berbagai kegiatan di Monas.

Dalam praktek kehidupan sehari-hari, seruan jihad dan berperang melawan Yahudi dan Amerika sebagai musuh bersama dalam bentuk memboikot produk-produk yang terindek milik perusahaan multi nasional yang berbasis di Barat selalu gagal. Dunia laskar tetap tidak bisa melepaskan diri dari produk-produk perusahaan multinasional. Hal ini karena umat Islam Indonesia khususnya daerah Solo tidak mampu memproduksi barang kebutuhan umat dengan kualitas dan harga yang bersaing dengan perusahaan-perusahaan yang diisukan untuk diboikot. Jadi gambaran musuh bersama dalam bentuk ekonomi belum mampu dihadapi, sebagaimana contoh yang lain adalah bertahannya minimarketminimarket putih merah padahal ada fatwa memboikotnya.

\section{Kontestasi Ruang Publik}

Pasca mundurnya President Soeharto, terjadi perebutan ruang publik oleh beberapa aliran ideology, ormas, atau party. Mereka merebutkan ruang pendidikan, media, pasar baik online maupun offline, ataupun ruang produksi wacana atau materi. Kasus perebutan ruang publik ini juga terjadi di Turkey. Pasca reformasi ekonomi 1990, kelompok islamisme turkey yang masuk dalam tarekat naqsabandy dan kelompok nurcu mengobtimalkan produksi tekstil yang berorientasi ekspor maupun kebutuhan dalam negeri. Mereka juga memproduksi makanan untuk memenuhi kebutuhan anggota jamaah. Kelompok tarekat naqsabandy dan nurcu ini mampu mengkonversi capital budaya menjadi capital ekonomi dengan menganjurkan anggota kelompoknya mengkonsumsi produk anggota jamaah. Perputaran ekonomi kelompok islamisme ini mencapai 30\% dari nilai ekonomi nasional. Mereka menguasai ruang produksi dan pasar, minimal yang berkaitan dengan kebutuhan anggota jamaah mereka. Pola ini mampu menjaga identitas keislaman kelompok Naqsabandy dan Nurcu di tengah gelombang sekulerisme di Turkey. ${ }^{48}$

Nilufer Gole menyatakan fenomena islamisme baru di ruang publik Barat yang sekuler. Para aktivis agama yang sudah menerima dan bisa bergaul dalam system sekuler Barat tetapi tetap menampilkan symbol-simbol identitas Islam. Para aktivis agama sudah muncul dalam perdebatan, perempuan berpenampilan modes dengan model dan warna ala Barat tetapi tetap menutup aurat. Jadi, pola negosiasi antara tokoh agama dalam ruang publik di Barat yang sekuler, modern dan maju adalah dengan menginternalisasikan mordrnitas dalam diri seorang muslim dengan tetap menjaga identitas keislaman. Meskipun tetap ditolak menjadi anggota parlemen di Turki pada tahun 1999, para tokoh sekuler Turki kesulitan menggambarkan dan menuduh Merve Kavakç sebagai orang islamist anti sekuler dan modernitas. Hal ini karena Kavakç merupakan seorang wanita yang mendapat gelar nsyinyur dari univertitas Texas yang mampu berbahasa Inggris dengan lancar dan berpenampilan modernis dengan kaca tanpa frame, pakaian potongan atas bawah yang berwarna warni dan

${ }^{48}$ M. Hakan Yavuz, "Ruang-Ruang Kesempatan, Identitas, Dan Makna Islam Di Turki," in Gerakan Sosial Islam; Teori, Pendekatan Dan Studi Kasus (YOGYAKARTA: Gading Publishing, 2012), 493-523. 
memakai jilblab. Inilah negosiasi para tokoh agama yang mengfokuskan perubahan yang berorientasi masyarakat. ${ }^{49}$

Sementara laskar mantan preman kesulitan merebut ruang publik yang tersedia. Penguasaan empat capital, yakni; capital budaya, ekonomi, sosial dan simbolik, untuk menguasai arena sebagaimana pendapat Bourdiew tidak semua dimiliki laskar..$^{50}$ Mereka ratarata berasal dari keluarga kelas menengah ke bawah. Mereka kesulitan untuk membuka usaha yang membutuhkan modal uang. Untuk itu, kehidupan para laskar ini bertumpu pada pedagang kecil di pasar, menjadi kuli bangunan, mencari barang bekas, atau bekerja di orangorang dari etnis Arab yang menguasai ekonomi daerah Semanggi Pasar, Kliwon.

Kesulitan para laskar mantan preman dalam ruang pasar atau ekonomi karena mereka juga lemah dalam kapital sosial. Mereka tidak memiliki akses untuk bekerja secara formal di institusi formal atau di institusi swasta yang mensyaratkan lulusan pendidikan SMA sederajat. Hal ini karena rata-rata pendidikan mereka lulusan SD atau SMP, sebagian bahkan tidak memiliki ijazah SD. Rendahnya pendidikan formal ini juga mempengaruhi cara mereka belajar agama Islam. Mereka tidak terbiasa membaca buku, belajar atau mengikuti kajian yang bersifat urut secara pembahasan. Mereka cenderung mengikuti pengajian akbar dengan tema yang membangkitkan emosi atau masalah jihad. Modal sosial yang rendah ini menyebabkan nalar berfikir mereka pendek. Hal inilah menyebabkan mereka tidak mampu merebut ruang media yang berisi pertarungan wacana. Mereka hanya mengkonsumsi wacana di ruang media baik secara online maupun offline, bahkan ketika memberi komentar, komentar mereka mengikuti reaksi orang lain baik tokoh maupun asatid yang sesuai dengan asumsi mereka sendiri.

Kontestasi ruang publik pendidikan sedikit berbeda dengan kontestasi pada ruang media atau ekonomi. Meskipun tidak bisa mendirikan lembaga pendidikan, mereka tetap bisa menyekolahkan anak-anak mereka disekolah yang sesuai dengan kebutuhan mereka. Kebanyakan anak-anak para anggota laskar sekolah di SD Islam Amanah Ummah, Ar Risalah, Tarbiyatul Ummah, dan Tabarok. Sekolah-sekolah ini secara umum dikelola aktivis islamisme yang selaras dengan pemikiran laskar. Untuk menjaga netralitas kurikulum, sekolah dasar seperti Tarbiyatul Ummah, al Busro dan Tabarok tidak mau berkabung dengan dinas pendidikan atau kemenag. Mereka biasanya mengikutkan program paket untuk anak didik mereka. Kemudahan dalam pemberian legalitas lulusan ini, dimanfaatkan lembaga pendidikan itu untuk mengelola kurikulum sendiri meskipun konsekuensinya mereka tidak mendapat dana operasi sekolah atau bantuan-bantuan lain.

Penguasaan ruang publik yang dapat dilakukan para laskar adalah penguasaan otoritas non formal yang dulu dikuasai kelompok-kelompok preman sekuler. Pergeseran ini

${ }^{49}$ Nilufer Gole, "Islam in Publik: New Visibilities and New Imaginaries," Publik Culture 14, no. 1 (2002): 173-90.

50 Haryatmoko, Membongkar Rezim Kepastian; Pemikiran Kritis Post-Strukturalis (Yogyakarta: Kanisius, 2016), 44. 
menjadi hal yang membahagiakan bagi pengusaha muslim maupun non muslim. Uang keamanan yang dulu harus dibayarkan per bulan atau tahunan hilang dengan hilangnya otoritas non formal preman. Untuk itu, sebagian masyarakat merasa bahwa keberadaan laskar sangat penting sebagai kekuatan sosial penyimbang para preman sekuler. ${ }^{51}$ Penguasaan ruang otoritas ini berbanding lurus dengan tumbuhnya symbol-simbol agama di ruang public, seperti busana muslimah, cadar, gamis, kopiah dan lain-lainnya.

\section{Globalisasi dan Lokalisasi}

Globalisasi sebenarnya bahasa ekonomi yang menuntut pasar dunia yang bebas, tanpa batas Negara, tuntutan dibukanya ekonomi nasional, tanpa aturan yang ketat, dan secara umum adalah berkurangnya kontrol Negara atas sumber daya ekonomi nasional dan aliran modal internasional. Perdebatan dan kritik terhadap globalisasi dilakukan beberapa sarjana diantaranya adalah J.S. Furnivall dalam kasus dibukanya akses perusahaan multinasional tanpa batas dan aturan di Burma yang menyebabkan ancaman terhadap disintergritas Negara dan runtuhnya masyarakat. Tapi dalam tulisan ini, Ruediger Korff menitikberatkan pembahasan tentang globalisasi pada bagaimana isu global dilokalisasi dan mengalisa bagaimana isu lokal yang dimodifikasi menjadi isu global. Karena menurutnya, dominasi global berasal dari konteks lokal tertentu. ${ }^{52}$

Teori globalisasi ini menjadi penting dalam pembahasan laskar. Konflik antar oposisi di Iraq dan Suriah yang bersifat lokal menglobal dan menjadi isu dunia Islam. Kasus ISIS (Islamic State of Iraq and Syam) yang merupakan gerakan politik dan jihad di Iraq dan Syam dan berkonflik dengan tandzim-tandzim jihad lain di Suriah dan Iraq mempengaruhi kondisi laskar di Solo. Ruediger Korff menyatakan bahwa tujuan menglobalkan isu lokal adalah mencari dukungan untuk gerakan lokal tersebut. Hal ini juga terjadi pada ISIS dan tandzimtandzim Jihad yang berseteru di daerah konflik. Sebagian laskar di Solo menyatakan dukungan kepada ISIS dan sebagian laskar mendukung non ISIS. Dukung terhadap ISIS berdampak pada identitas laskar melebur dengan identitas ISIS. Fatwa takfir ISIS kepada mujahidin di Iraq dan Suriah yang tidak berbaiat kepada al Baqdadi juga menular pada pemikiran laskar pendukung ISIS yang mengkafirkan orang yang tidak mendukung khilafah.

ISIS berawal dari invasi Amerika ke negara Iraq dan menjatuhkan pemerintahan Saddam Husein. Abu Mus'ab az Zarqawi (salah satu pimpinan al Qaida) masuk ke Iraq dan membentuk Jamaah at-Tawhid wal Jihad. JTJ melakukan berbagai aksi perlawalan terhadap pasukan Amerika dan pasukan pemerintahan Iraq yang mereka tuduh sebagai pamerintahan boneka. Pada Januari 2006, al Qaeda memerintahkan JTJ dan jamaah jihad yang berafiliasi dengan al-Qaeda untuk bersatu. Para komandan jihad ini kemudian bersatu menjadi Mujahidin Shura Council dan az Zarqawi sebagai pemimpin. Setelah Abu Mus'ab az Zarqawi syahid pada 7 Juni 2006, MSC mendirikan Islamic State of Iraq (ISI) dan membai' at

${ }^{51}$ Kafid, "Dari Islamisme Ke 'Premanisme’: Pergeseran Orientasi Gerakan Kelompok Islam Radikal Di Era Desentralisasi Demokrasi.”

52 Ruediger Korff, “Local Enclosures of Globalization. The Power of Locality,” Dialectical Anthropology 27, no. 1 (2003): 1-18. 
Abu Umar sebagai pemimpin mereka. ISI kemudian membentuk kabinet dan perangkat pemerintahan. ISI berkembang dan wilayahnya bertambah. ${ }^{53}$

Pada 18 April 2010, Abu Umar meninggal karena serangan Amerika dan pasukan Iraq. ISI kemudian mengangkat Abu Bakar al Baghdadi sebagai pemimpin mereka. Pada 9 April 2013, ISI berubah menjadi ISIS yang wilayah mencakup Fallujah, Mosul dan Raqqa. Pada periode ini, perselisihan antara ISIS dan al-Qaeda meruncing. ISIS yang sebelumnya cabang al-Qaeda dan difokuskan pada aksi jihad wilayah Iraq mulai meluaskan aksi di negeri Syam yang menjadi wilayah operasi Jabhah Nusra. Perselisihan semakin memburuk ketika ISIS berubah menjadi IS Islamic State atau kekhilafan islamiyah yang menuntut kepada seluruh fraksi jihad baik di Iraq, Syam maupun belahan dunia manapun untuk membai'at Abu Bakar al-Baghdadi sebagai kholifah dan melepas semua bai'at dari jamaah-jamaah lain. Bai'at adalah janji taat kepada pemimpin, menyerahkan ketentuan bertindak dalam kehidupan pribadi dan umum serta berjanji untuk tidak menyelesihi perintah dan kebijakan pemimpin. Mereka bahkan menghukumi murtad orang yang tidak ikut berbait dan halal diperangi. Kaidah ini memperburuk konflik antar ISIS dan fraksi jihad yang lain di Iraq dan Syam. ${ }^{54}$

Logika kewajiban berbaiat ini didasarkan pada perintah Nabi Muhammad SAW kepada kaum muslimin untuk membaiat seorang pemimpin dan ancaman suul khotimah bagi yang meninggal dalam keadaan tidak berbaiat. ${ }^{55}$ Selain itu, ISIS juga menyerang tandhim jihad lain karena prinsip baiat harus pada satu pemimpin, ketika ada pemimpin-pemimpin lain yang dibaiat, maka jamaah itu harus diperangi. Sebagaimana perintah Nabi Muhammad SAW untuk memerangi salah satu dari khalifah yang dibai'at. "jika dua khalifah dibai'at, maka perangilah yang tarakhir dari keduanya". ${ }^{66} \mathrm{Hal}$ ini ditafsirkan oleh ISIS sebagai bai' at tunggal.

Deklarasi ISIS menjadi Negara Islam disambut dengan berbagai reaksi di belahan dunia termasuk Indonesia. Sebagain umat Islam mendukung sementara sebagian yang menolak. Para pendukung ISIS di Sukoharjo membentuk Forum Pendukung Daulah Islamiyah (FPDI) yang ketua Amir Machmud dan Afif Abdul Madjid. Forum ini mendeklarasikan dukungan mereka di Masjid Baitul Makmur Grogol Sukoharjo pada 15 Juli 2014. Dukungan serupa juga dideklarasikan oleh Jamaah Ansharu Khilafah di Lowokwaru Malang pada 20 Juli 2014. Forum Aktivis Syariah Islam (FASI) di Tangerang Selatan juga mendeklarasikan dukungan kepada ISIS di UIN Syarif Hidayatullah pada 8 Februari $2014 . .^{57}$

\footnotetext{
53 Fernando PM Tambunan, "Sejarah Dan Ideologi ISIS (Islamic State of Iraq and Sham)," Unpublished Master Thesis, Universitas Indonesia, Jakarta, 2014.

${ }^{54}$ Kataib Rad' Khawarij, Pandangan 45 Ulama Jihad Internasional Tentang ISIS (Solo: Jazera, 2016), $40-45$

${ }^{55}$ Hadist No 1851. Muslim, Al Musnad as Shahih Al Mukhtasor Bi Naqli Al Adl Dari Al Adl Ila Rasulullah (Beirut: Darul ihyau al Turast al Arabi, n.d.) (barang siapa yang meninggal dan tidak berbaiat, maka ia mati seperti matinya orang jahiliyah).

${ }^{56}$ Hadist 1853 Muslim.

57 Joko Tri Haryanto, "Perkembangan Gerakan ISIS Dan Strategi Penanggulangannya (Kasus Perkembangan Awal ISIS Di Surakarta),” Harmoni 14, no. 3 (2015): 23-40.
} 
Pada tahun 2014, Ustad Abu Bakar Ba'asyir menyatakan bahwa beliau membait Abu Bakar al Bagdadi sebagai kholifah pemimpin umat Islam di dunia. Sebagai bentuk baiat, maka beliau membubarkan Jamaah Ansharut Tauhid yang dipimpinnya. Beliau berpendapat bahwa cita-cita perjuangan dan dakwah Islam yang dilakukannya dari dulu sampai hari ini adalah tegaknya kekhilafan di dunia, maka ketika daulah Islamiyah telah tegak, maka kewajiban semua gerakan Islam adalah mendukung dan membantu daulah tersebut. Dukungan Ustadz Abu Bakar Ba'asyir terhadap daulah Islamiyyah ini menunai kritik sebagian pimpinan Jamaah Ansharut Tauhid yang berakhir dengan perpecahan ditubuh anggota jamaah ini dan memunculkan Jamaah Anshorus Syari'ah. ${ }^{58}$

Sebagian pengurus Jamaah Ansharut Tauhid melihat bahwa keputusan beliau membai' at Abu Bakar al Baghdadi sebagai keputusan yang tergesa-gesa. Mereka berpendapat bahwa kemunculan daulah baru harus dilihat perkembangan apalagi kemunculan ISIS menyebabkan konflik antar mujahidin. Tokoh utama JAS adalah ust Abdurrohiim Ba'asyir (putra ketiga ustadz Abu Bakar Ba'asyir). Dia tidak sepakat dengan pendapat bapaknya bahwa puncak tertinggi perjuangan adalah berdirinya daulah islamiyah. Dia berpendapat bahwa puncak perjuangan adalah tegaknya syari'at Islam. Dia menambahkan bahwa berdirinya daulah islamiyah tetapi bertentangan syari' at Islam malah mencoreng nama Islam. Dia menyatakan bahwa ISIS termasuk daulah yang bertentangan dengan syari'at Islam karena menghukumi murtad para mujahidin yang berperang di Suriah yang tidak mau berbait kepada Abu Bakar al Bagdadi. Dia juga menambahkan bahwa kebedaan ISIS tidak menambah kebaikan baik di daerah konflik Iraq dan Syam maupun perjuangan Islam di belahan bumi yang lain. ${ }^{59}$

Perselisihan antara ISIS dan fraksi-fraksi jihad di Suriah berdampak pada perpecahan persatuan laskar di Solo. Sebagian mereka bergabung dengan ISIS dengan meleburkan jamaah mereka dengan Jamaah Anshoru Daulah (JAD) sebagian mereka tidak mau membaiat Abu Bakar al Baghdadi bahkan cenderung menyalahkan keberadaan ISIS yang membalikan keadaan para mujahidin di Suriah menjadi terpojok. Mereka merasa simpatik kepada mujahidin Ahrar Syam, FSA, Jabhah Nusra, dan fraksi-fraksi lain yang dituduh murtad dan diserang ISIS. ${ }^{60}$ Perselisihan ini berdampak pada rasa wala' (persahabatan) dan bara' (permusuhan). Permasalahan utama adalah takfir kepada pemerintah dan pendukungnya. Mereka juga menganggap orang yang ikut pemilu sebagai pendukung pemerintah dan demokrasi sehingga dihukumi murtad. Ideologi takfir menjadikan pengikut ISIS juga mengkafirkan laskar dan ustad yang tidak mendukung atau bahkan menentang daulah. ${ }^{61}$

\section{Penutup}

Dimensi kehidupam laskar mantan preman menarik untuk dibahas. Konversi identitas preman menjadi laskar merupakan realitas menarik karena ini merupakan dua kutub yang berbeda. Perubahan mereka sangat ekstrem, dari preman menjadi ikhwan atau

\footnotetext{
${ }^{58}$ Wawancara dengan Ust Sholeh Ibrohim, Bergabungnya JAT ke ISIS, September 15, 2018.

59 Wawancara dengan Ust Abdurrohim Ba'asyir, Sikap JAS Terhadap ISIS, September 16, 2018.

${ }^{60}$ Kataib Rad' Khawarij, Pandangan 45 Ulama Jihad Internasional Tentang ISIS, 45.

${ }^{61}$ Wawancara dengan Ust Abdurrohim Ba'asyir, Sikap JAS Terhadap ISIS.
} 
laskar. Tetapi dunia laskar yang keras merupakan habitat yang cocok bagi para mantan preman untuk berubah. Perubahan ini merupakan hasil negosiasi identitas lama ke identitas yang baru. Sebenarnya, perubahan identitas menjadi aktivis Islam melalui tiga tahapan, yakni; ta'rif, taqwin dan tanfidz. Terjadinya loncatan dari ta'rif ke tanfidz membuat laskar kurang memahami hakikat dari gerakan Islamisme.

Konversi preman menjadi laskar membuat kondisi sosial daerah-daerah merah menjadi kondusif. Harta tanah menjadi naik, keamanan lebih terjaga, dan masjid-masjid makmur dengan jamaah terutama pada sholat magrib dan isya'. Selain membuat suasana kondusif, konversi preman menjadi laskar meninggalkan beberapa PR bagi para ustad, stake holder, komandan laskar dan masyarakat dimana sebagian preman belum mampu mengkoversi identitas diri mereka dengan baik. Logika preman masih mempengaruhi pangamalan keagamaan. Selain itu, ada beberapa preman yang berkamuflase menjadi laskar untuk kepentingan diri. Proses konversi mereka menjadi laskar secara umum karena hilangnya wibawa mereka dalam dunia preman, takut pada laskar atau untuk kepentingan ekonomi. Untuk itu, penulis mengklasifikasi laskar menjadi dua, laskar moderat yang memiliki tujuan untuk kemaslahatan kehidupan sosial dan laskar kamuflase yang menggunakan identitas laskar untuk kepentingan pribadi atau golongan.

Mayoritas laskar mantan preman berpendidikan rendah, dari keluarga menengah ke bawah, dan kurang terlatih membuat mereka tidak bisa merebut ruang publik yang banyak dibuka pasca reformasi. Mereka lemah dalam produksi wacana, penguasaan pasar ekonomi, dan ruang pendidikan. Meskipun mereka lemah dalam beberapa ruang publik diatas, mereka masih memiliki modal untuk menguasai otoritas non formal yang dulu dikuasai preman sekuler. Hal ini mendorong munculnya symbol-simbol agama di ruang publik.

Bencana muncul ketika globalisasi mempengaruhi kondisi lokal. Perpecahan mujadihin di Iraq dan Suriah menyebabkan perpecahan jamaah laskar di Solo. Mereka terbelah menjadi dua, antara pendukung ISIS dan penolak ISIS. Perpecahan semakin tajam dengan ideologi takfiri. Laskar pendukung ISIS mengkafirkan orang-orang yang menentang daulah dan mengkafirkan pemerintah serta semua perangkat dan pendukungnya. Mereka bahkan mengkafirkan para peserta pemilu. Ideologi takfiri ini merusak hubungan sosial di tengah laskar dan perjuangan umat Islam di Solo.

Realita dunia preman akan terus menjadi daya Tarik peneliti untuk memahaminya dari berbagai pendekatan, baik ekonomi, politik, psikologi, keamanan atau pendekatan yang lain.

\section{Daftar Pustaka}

Abu Fida Ibnu Katsir. Tafsir Al-Qur'an Al-Adhim. Beirut: Darul Fikri, 1997.

Ahmad bin Hambal. Musnad Al-Imam Ahmad Bin Hambal. 18 vols. Beirut: Muasasah arRisalah, 2001.

Bayat, Asef. "Islamism and Social Movement Theory." Third World Quarterly 26, no. 6 (2005): 891-908.

Castells, Manuel. The Power of Identity. Second. UK: Wiley-Blagkwell, 2009. 
Gole, Nilufer. "Islam in Public: New Visibilities and New Imaginaries." Public Culture 14, no. 1 (2002): 173-90.

Haryanto, Joko Tri. "Perkembangan Gerakan ISIS Dan Strategi Penanggulangannya (Kasus Perkembangan Awal ISIS Di Surakarta).” Harmoni 14, no. 3 (2015): 23-40.

Haryatmoko. Membongkar Rezim Kepastian: Pemikiran Kritis Post-Strkturalis. Yogyakarta: PT Kanisius, 2016.

In'am Esha, Muhammad. "KEPEMIMPINAN DI ERA DEMOKRASI DELIBERATIF." El-QUDWAH, 2014.

Ismail, Salwa. "Being Muslim: Islam, Islamism and Identity Politics." Government and Opposition 39, no. 4 (2004): 614-31.

Jum'ah Amin Abdul Aziz. Fiqih Dakwah. Solo: Era Intermedia, 2000.

Kafid, Nur. "Dari Islamisme Ke 'Premanisme': Pergeseran Orientasi Gerakan Kelompok Islam Radikal Di Era Desentralisasi Demokrasi.” MASYARAKAT: Jurnal Sosiologi, 2016, 57-79.

Kataib Rad' Khawarij. Pandangan 45 Ulama Jihad Internasional Tentang ISIS. Solo: Jazera, 2016.

Korff, Ruediger. "Local Enclosures of Globalization. The Power of Locality.” Dialectical Anthropology 27, no. 1 (2003): 1-18.

Kuntowijoyo. Paradigma Islam: Interpretasi Untuk Aksi. Bandung: Mizan, 1998.

M. Hakan Yavuz. "Ruang-Ruang Kesempatan, Identitas, Dan Makna Islam Di Turki.” In Gerakan Sosial Islam; Teori, Pendekatan Dan Studi Kasus, 493-523. YOGYAKARTA: Gading Publishing, 2012.

Mahmood, Saba. Politics of Piety: The Islamic Revival and the Feminist Subject. Princeton University Press, 2011.

Muhammad Tholhah Hasan. Prospek Islam Dalam Menghadapi Tantangan Zaman. Ke-Lima. Jakarta Selatan: Lantabora Press, 2005.

Munirul Ikhwan. "Produksi Wacana Islam(Is) Di Indonesia." In Literatur Keislaman Generasi Milenial; Transisi, Apropriasi, Dan Kontestasi, 63-108. Yogyakarta: Pasca Sarjana UIN Sunan Kalijaga Press, 2018.

Muslim. Al Musnad as Shahih Al Mukhtasor Bi Naqli Al Adl Dari Al Adl Ila Rasulullah. Beirut: Darul ihyau al Turast al Arabi, n.d.

Musthafa Masyur. Fiqih Dakwah. Kedua. Jakarta: Al-I'tishom Cahaya Umat, 2001.

Noorhaidi Hasan. Laskar Jihad. Jakarta: Pustaka LP3ES, 2008.

Saloom, Gazi. "IDENTIFIKASI KOLEKTIF DAN IDEOLOGISASI JIHAD.” Jurnal Dialog 38, no. 1 (2015): 1-12.

. "Jihad Dan Thâ’ifah Manshûrah: Basis Syariah Identitas Kelompok Jihadis." AHKAM: Jurnal Ilmu Syariah 16, no. 1 (2016).

Tambunan, Fernando PM. "Sejarah Dan Ideologi ISIS (Islamic State of Iraq and Sham)." Unpublished Master Thesis, Universitas Indonesia, Jakarta, 2014.

Umat Islam Bongkar Kejahatan Densus 88 Di Muka FKPT. Accessed September 28, 2018. https://www.tribunislam.com/2014/09/umat-islam-bongkar-kejahatan-densus-88di-muka-fkpt.html.

Ust Abdurrohim Ba'asyir. Sikap JAS Terhadap ISIS, September 16, 2018. 
160 Konversi Identitas Preman ....

Ust Sholeh Ibrohim. Bergabungnya JAT ke ISIS, September 15, 2018.

Vel, Jacqueline AC. Uma Politics: An Ethnography of Democratization in West Sumba, Indonesia, 1986-2006. Vol. 260. Brill, 2008.

Wahbah al-Zuhayly. Al-Fiqh Al-Islami Wa Adilatuh. Damaskus: Darul Fikri, 1989.

Warsito. Preman Taubat. Solo: Penerbit al Aqwam, 2016.

Wasisto Raharjo Jati. "Kuasa Dan Kekerasan: Kelembagaan Premanisme Yogyakarta Paska

Reformasi." Jurnal Sosiologi Islam 2, no. 1 (2012): 61-76. 